\title{
FACTORES QUE CONDICIONAN LA APROPIACIÓN DEL CONOCIMIENTO Y SU DURABILIDAD EN LA ASIGNATURA QUÍMICA EN ALUMNOS DE INGENIERÍA AGRONÓMÍCA
}

\author{
Nescier, I. de los M. ${ }^{1}$; Althaus, R. L. ${ }^{2}$ \& Rocha, A. M. ${ }^{3}$
}

\begin{abstract}
RESUMEN
En el presente trabajo de investigación educativa se analizaron los factores condición del alumno (CA) y terminalidad de la escuela secundaria (ES) sobre los aprendizajes en Química Analítica General y Aplicada (QAGA) logrados por los alumnos de Agronomía de la UNL y su durabilidad.

Se consideraron los resultados de evaluaciones parciales, exámenes y evaluaciones diagnósticas, tomando como eje los temas "Reacciones de oxidación reducción" y "Electroquímica", desarrollados con la metodología de aprendizaje basado en la resolución de problemas (ABP) en forma cooperativa.

Se observó un efecto significativo para el factor CA, ya que los alumnos recursantes obtuvieron menores calificaciones que los alumnos ingresantes. En el segundo año de cursado, no se observaron diferencias significativas por el factor ES, ya que dicho efecto ha sido nivelado en la asignatura Química General e Inorgánica (QGI), por lo que se puede establecer que éste no es un factor limitante del aprendizaje una vez que los alumnos han avanzado en la carrera. La durabilidad de los aprendizajes logrados en asignaturas previas resultó escasa.
\end{abstract}

Palabras clave: aprendizaje significativo, durabilidad, escuela secundaria.

\section{SUMMARY}

\section{Factors that condition the appropiation of the knowledge in chemistry and its durability in students of Agronomic Engineering.}

In this paper of educational research the factors student's condition (CA) and terminality of the high school (ES) were analyzed on the learning in General and Applied Analytic Chemistry achieved by the students of agronomy of the UNL and their durability.

The results of partial evaluations, exams and diagnostic evaluations were considered, taking as axis the topics "Reactions of oxidation reduction" and "Electrochemistry", developed with the learning methodology based on the resolution of problems (ABP) in cooperative form.

A significant effect was observed for the factor $\mathrm{CA}$. The student of previous years obtained smaller qualifications that the students that entered in that year. In factor is significant differences were not observed in the second year. This effect has been balanced in the General and Inorganic Chemistry (QGI) subject, reason why it would noy be limiting factor in the learning once the students have advanced in the career. The durability of the learning achieved in previous subjects was scarce.

Keyd words: significant learning, durability, high school.

1.- Cátedra de Química. Facultad de Ciencias Agrarias, Universidad Nacional del Litoral. Kreder 2805. (3080) Esperanza, Santa Fe. Telefax: (03496) 426400. Email: inescier@fca.unl.edu.ar

2.- Cátedra de Biofísica. Facultad de Ciencias Veterinarias, UNL.

3.- Escuela Normal Superior $N^{\circ} 30$ D. F. Sarmiento. Sarmiento 2644. (3080) Esperanza, Santa Fe. Manuscrito recibido el 19 de setiembre de 2007 y aceptado para su publicación el 28 de febrero de 2008. 